\section{Валерій Ластовський}

доктор історичних наук, професор

Київський національний університет

культури і мистецтв

(Київ, Україна)
Valerii Lastovskyi

Doctor of Historical Sciences

(Dr. Hab. in History), Professor, Professor of Department of International Relations, Kyiv National University of Culture and Arts, (Kiyv, Ukraine)

lastov@ukr.net

ORCID: https://orcid.org/0000-0001-8900-5569

ResearcherID: V-2549-2018

\title{
ДВІ ВІЗАНТІЙСЬКИХ МОНЕТИ 3 ТЕРИТОРЇ̈ МОТРОНИНСЬКОГО МОНАСТИРЯ ТА ЛЕГЕНДА ПРО ЙОГО ЗАСНУВАННЯ КНЯГИНЕЮ МОТРОНОЮ
}

\author{
TWO BYZANTINE COINS FROM THE TERRITORY OF MOTRONIN \\ MONASTERY AND THE LEGEND OF ITS ESTABLISHMENT \\ BY PRINCESS MOTRON
}

\section{Анотація.}

У статті досліджується ситуація з трансформацією інформації нумізматичного матеріалу у процесі його виявлення і подальшого використання як у наукових, так $i$ в інших цүілях. У науковому середовищі інформація щзодо монет, виявлених на території Мотронинського городища на початку XIX століття, частково так $i$ не була оприлюднена, а частково була змінена в результаті допущеенх помилок. Одночасно від початку XIX cm. населення Чигиринщини (нинішня Черкаська область) у своєму повсякденному житті інформащію щуодо виявлених монет трансформувало у легенду про княгиню Мотрону, яка начебто заснувала православний Тройцький Мотронинський монастир. У статті доводиться, щуо насправді виникнення иієї легенди пов'язане виключно з помилкою, допущеною при первинній ідентифікації візантійських фолісів імператорів Юстиніана I та Юстина II. Водночас прослідковуються етапи поширення інформації про візантійські монети та легенди про княгиню Мотрону. 3'ясовуються моменти, пов'язані з часом можливого виявлення монет та їх дослідженням на початку ХІХ століття. Крім того, з метою формування найточніших уявлень щзодо монетного матеріалу, виявленого на території Мотронинського монастиря, відтворюється первинна інформація про дану знахідку, яка була зафіксована у статті Ф. Круга та в архівних документах изієї обителі.

Ключові слова: Троӥцььий Мотронинський монастир, Чигиринщина, легенда, княгиня Мотрона, візантійський фоліс, Йоганн Філіп Круг, Микола Рум'янщев. 


\section{Summary.}

The article investigates the situation with the transformation of information of numismatic material in the process of its detection and further use for both scientific and other purposes. In the scientific community, information about the coins found at the Motroninsky settlement in the early nineteenth century was partly not made public, and partly changed as a result of mistakes. At the same time, in the daily life of the population of Chyhyryn region (now Cherkasy region) from the beginning of the XIX century. information about the discovered coins was transformed into a legend about Princess Motrona, who allegedly founded the Orthodox Trinity Motrona Monastery. The article argues that, in fact, the origin of this legend is due solely to a mistake made in the initial identification of the Byzantine follies of the emperors Justinian I and Justin II. At the same time, the stages of spreading information about Byzantine coins and legends about Princess Motrona are traced. The moments connected with the moment of possible discovery of coins and their research in the beginning of the XIX century are found out. In addition, in order to form the most accurate ideas about the coin material found on the territory of the Motroninsky monastery, its primary information is reproduced. It was recorded in an article by F. Krug and in the archival documents of this monastery.

Key words: Trinity Motroninsky Monastery, Chyhyryn region, legend, Princess Motrona, Byzantine folly, Johann Philip Krug, Mykola Rumyantsev.

Вступ. У нумізматиці як науковій історичній дисципліні багато уваги приділяється найрізноманітнішим аспектам монет, їх виробництву, обігу, фальшуванню чи стану збереження; крім того, оцінюється їх зв'язок з культурою, політикою, економікою тощо. Усьому цьому присвячено безліч статей та монографій. Однак з часом, розглядаючи більш детально ті чи інші історичні процеси та події, ми спостерігаємо, як відбувається спотворення інформації, що призводить, зрештою, до викривлених висновків та утворення наукових міфів. Певним міфотворчим елементом інколи може виступати й монетний матеріал. Саме таку ситуацію ми можемо побачити у випадку з двома візантійськими монетами, що були випадково знайдені на початку XIX століття.

Постановка проблеми. У даному випадку існує потреба 3'ясування наукової ситуації у двох площинах: 1) виявлення в конкретній ситуації впливу монетного матеріалу на появу народної легенди; 2) відтворення первинного інформаційного матеріалу, пов'язаного з атрибуцією знайдених монет, у зв'язку з тим, що в науковій літературі існують певні помилки в їх описі.

Аналіз останніх досліджень і публікацій. Література, в якій в тому чи іншому контексті згадуються візантійські монети, знайдені у Мотронинському монастирі, достатньо презентативна. Разом з тим, переважно в такого роду джерелах ці монети лише згадуються або ж дублюють відповідну інформацію з більш ранньої літератури. Зокрема, такий матеріал представлений у роботах Амвросія (Орнатського), Л. Похілевича, М. Біляшівського, О. Бобринського, В. Кропоткіна та ін. Питання ж, яке тут досліджується, ще не було предметом наукового розгляду.

Мета статті визначається потребою більш детального аналізу нумізматичного матеріалу з Мотронинського городища та його використання в науковій літературі; потребою з'ясувати його роль у формуванні уявлень місцевого населення.

Виклад основного матеріалу дослідження. Троїцький Мотронинський монастир знаходився у XVII - на початку XX ст. на території нинішньої Черкаської області, поруч із селом Мельники, на території відомого Мотронинського городища. Як правило, цей монастир в історичній науці ототожнювався, у першу чергу, $з$ діяльністю у 1760-х роках 
його ігумена Мельхіседека Значко-Яворського та вибухом Коліївщини у 1768 р. ${ }^{1}$ Але впродовж XIX - початку XXI століття з ним була пов'язана і широко поширена серед місцевого населення легенда про заснування цього монастиря міфічною княгинею Мотроною. Однак, фактично невідомою залишається та обставина, що виникнення цієї легенди було пов'язане із тутешньою знахідкою двох візантійських монет на початку XIX ст. Тут не можна не погодитися із Віктором Коцуром щодо наявності тісного зв'язку скарбів із українським фольклором².

Уперше інформація про виявлення візантійського монетного матеріалу на території Мотронинського городища 3 прив'язкою до легенди про княгиню Мотрону була опублікована у 1813 році. Оприлюднив її відомий церковний діяч Амвросій (Орнатський) (1778-1827), на той момент - очільник Духовної Цензури у Москві та архімандрит московського Новоспаського монастиря: «Название свое монастырь и около лежащий лес получил Мотренинский от Матроны княгини, владетельницы места сего, жившей тут до нашествия Батыева на Россию. Мнение сие утверждает земляное укрепление, уже поросшее лесом близ монастыря в виде вала находящееся, и монета княгини оной хранящаяся в монастыре. Год и цена оной неизвестны».

Незабаром з'явилось і роз'яснення стосовно окресленої ситуації. У 1819 році була опублікована стаття у журналі «Вестник Европы» авторства відомого фахівця 3 нумізматики - Йоганна Філіпа Круга (1764-1844) ${ }^{4}$. Вона 3’явилася спочатку як листвідповідь на прохання канцлера, графа Миколи Рум'янцева (1754-1826). Причому, відповідь була написана німецькою мовою, а опублікована як стаття вже в перекладі російською.

Дослідник у своїй відповіді надзвичайно детально описав саму монету та історію iї чеканки. А насамкінець вже відзначив, що хоч і вважає книгу «История российской иерархии» дуже корисною, тим не менше, слова, присвячені княгині Мотроні, «должно вовсе, на мою ответственность, вычернить».

Після цього візантійські монети з Мотронинського городища та легенда про княгиню Мотрону починають жити своїм окремим життям. Їх уже ніхто і ніколи не пов'язує в єдине ціле.

Історія візантійських монет більшою мірою відслідковується вже у наукових публікаціях. Самі вони досить довгий час зберігалися в самому монастирі. Як видно із публікації ще Ф. Круга, спочатку із монастиря через канцлера М. Рум’янцева монети потрапили до рук дослідника, а потім, вочевидь, таким же шляхом повернулися і назад. У 1830-х роках ці монети фігурують у переліку монастирських речей, «достойных замечания» ${ }^{5}$. Залишалися вони там ще і в 1872 році, про що записав в автобіографії Микола Костомаров (1817-1885), котрий там побував разом із Павлом Чубинським (18391884): «Архимандрит показал мне... несколько золотых и серебряных монет, выкопанных в валу, окружающем монастырь. Монеты эти византийские, первых веков существования Византийской империи. Они заставляют предполагать, что в эти далекие времена на месте, окаймленном один за другим валами, существовало поселение, входившее в торговые связи с византийским миром» ${ }^{6}$. Історик тут пише, що йому показували золоті та срібні візантійські монети. Відповідно, це наштовхує на думку, що або він у чомусь помилився, або ж у монастирі були знахідки й інших монет, які оминули око вчених. Адже ті монети, які увійшли до наукового обігу на початку XIX ст., були мідними. Тоді ж була

\footnotetext{
Ластовський В. Між суспільством і державою. Православна церква в Україні наприкінці XVII - у XVIII ст. в історії та історіографії. К., 2008. $496 \mathrm{c}$.

2 Коцур В. Історіографія українського скарбознавства // Український нумізматичний щорічник. Вип. 1. 2017. С. 17.

История российской иерархии. Часть V. М., 1813. С. 109.

Круг Ф. О мнимо Матренинской монете // Вестник Европы. 1819. Часть 103. №3. С. 195-198.

ЦДІАУК. Ф. 180. Оп. 1. Спр. 19. Арк. 5.

${ }^{6}$ Костомаров Н. Исторические произведения. Автобиография. К., 1989. С. 623-624.
} 
знайдена іще одна срібна польська монета Сигізмунда III, про яку не згадується в наукових публікаціях, але яка відзначена серед переліку монастирських речей. Та навряд чи такий вчений, як Микола Костомаров, міг сплутати монету рубежу XVI-XVII ст. iз візантійською монетою VI ст. Тому наведену вище його тезу слід розцінювати як певну загадку або ж непорозуміння.

Після інформації М. Костомарова слід самих візантійських монет губиться. Але із середини XIX століття вони вже стали об'єктом інтересу науковців виключно вузьких інтересів. Вихідною точкою для поширення інформації про них стала передовсім праця Лаврентія Похілевича (1816-1893), присвячена населеним пунктам Київської губернії. Від дав достатньо точний опис цих монет 3 посиланнями на працю київського митрополита Євгенія (Болховітінова) (1867-1837) «Киевский месяцеслов, с при совокуплением разных статей к российской истории и киевской иерархии относящихся» (1832). Принагідно зауважимо, що митрополит був фактичним співавтором (хоча офіційно це не було відзначено) тієї «Истории российской иерархии», на сторінках якої вперше з'явилася інформація про знайдену візантійську монету, княгиню Мотрону i заснування нею Мотронинського монастиря.

Далі згадки про візантійські монети знаходимо у працях М. Біляшівського, О. Бобринського, В. Антоновича та ін. ${ }^{2}$ Слід відзначити, що інколи ці згадки відрізнялися між собою за інформацією та описом легенд монет. Найбільш повний опис у сучасній нумізматиці належить радянському нумізмату і археологу Владиславу Кропоткіну (19221993), але, зрозуміло, він був здійснений автором уже на основі історіографічних джерел, оскільки працювати із самими монетами дослідник вже не міг ${ }^{3}$. Недостатнім у цьому випадку було те, що вчений описав лише одну монету - фоліс Юстинінана I, а опис другої монети був ним опущений. Це пояснюється тим, що у публікації Ф. Круга (1819) так само була описана лише одна монета, а не обидві.

Востаннє ж ці візантійські монети з'явилися у наукових публікаціях 2007 р. у нумізматичному довіднику знахідок на Черкащині Анатолія Шостопала (автор у своєму тексті йшов за В. Кропоткіним $)^{4}$.

Оскільки детальної інформації по опису монет на сьогодні в літературі немає, навіть більше - вона суперечлива й неповна, вважаю за необхідне нижче навести ту інформацію, яка первинна, а саме матеріали з публікації Ф. Круга та архівний опис із самого Мотронинського монастиря.

У 1818 році Йоганн Філіп Круг (свого листа він написав 30 грудня цього ж року) описав одну із виявлених монет таким чином:

«На одной стороне:

Поясной портрет государя, украшенный короною или венцем на голове, с перьями или волосами и с повисшею вниз повязкою; в правой руке государя держава с крестиком вверху, в левой щит перед грудью, на коем изображен всадник. Близ головы влево большой продолговатый крест. Надпись следующая: DNIUSTINI ANUSPPAU то есть: Dominus Noster Iustinianus Pater Patriae Augustus (Государь наш Юстиниан, отец отечества августейший).

На другой стороне:

В средине литера М, т.е. числительная буква, означающая 40... Литера А, в литере М находящаяся, означает, что монета сия чеканена на первом монетном дворе...

${ }^{1}$ Похилевич Л. Сказания о населенных местностях Киевской губернии. К., 1864. С. 688-689.

2 Беляшевский Н. Монетные клады Киевской губернии. К., 1889. С. 142; Бобринский А. Курганы и случайные археологические находки близ местечка Смелы. Т. ІІ. СПб., 1894. С. 58; Антонович В. Археологическая карта Киевской губернии. К., 1895. С. 112.

3 Кропоткин В. Топография римских и ранневизантийских монет на территории СССР // Вестник древней истории. 1954. №3. С. 152-180; Кропоткин В. Клады византийских монет на территории СССР. М., 1962. С. 37.

${ }^{4}$ Шостопал А. Скарби Черкащини. Черкаси, 2007. С. 35. 
Находящиеся на нижней части сей монеты буквы KYZ означают место чеканения оной, каковым должен быть город Cyzicus...» ${ }^{1}$

Серед архівних матеріалів колишнього Мотронинського монастиря до сьогодні зберігся документ 1830-х років (більш точна дата невідома) під назвою «Краткое историческое и статистическое сведение о Мотренинском заштатном монастыре», в якому було дано опис всього майна обителі, у т.ч. й тих монет, про які йшлося вище:

«К замечательным вещам должно отнести три монеты, найденные в здешних валах. - Две из них римские, а третья польская. На $1^{\text {й }}$ из них надпись следующая: D.N. Jnsti_nianus P.P. Avg. me, Государь наш Јустиниан отец отечества августейший.

Другая монета имеет изображение императора Јустина и супруги его императрицы Софии, сидящих на престоле и держащих в руках скипетр и шар. По краям монеты слова D.N Jystinus P.P. Avgme, государь наш Јустин, отец отечества августейший.

3. Монета малая посребренная польского короля Сигизмунда III царствов. с 1587 по 1632 год имя его означено по краям монеты»².

Із усієї цієї інформації випливає, що виявлені монети відносилися до часів правління візантійських імператорів Юстиніана I (527-565) та Юстина II (565-578). Саме такий фоліс Юстиніана знаходимо в дослідженнях відомих британських нумізматів Уорвіка Уорота та Девіда Сіра ${ }^{3}$. Щодо монети Юстина II, то їі опис зустрічаємо у праці американського нумізмата Філіпа Вайтінга ${ }^{4}$.

На Чигиринщині такі монети зустрічалися і в інших випадках, зокрема й неподалік Мотронинського монастиря. А саме відомі знахідки фолісів Юстиніана I та Юстина II біля сіл Погорільці та Новоселиця ${ }^{5}$ Однак у цілому в Черкаському регіоні такого типу знахідки не досить поширені.

Легенда про заснування Мотронинського монастиря княгинею Мотроною набуває надзвичайно широкого поширення. Вона дуже швидко розповсюджується серед населення і далі перекочовує ще й у наукову літературу. Так, у 1843 році Пантелеймон Куліш (1819-1897) від смілянського жителя Кіндрата Таранухи записав, що дочка «якогось пана» Мотря «Мотренин монастир збудовала» ${ }^{6}$. Потім згадки про Мотрону якщо й бачимо в наукових працях, то лише зрідка. Наприклад, у 1864 р. - публікація П. Лебединцева (1819-1896), присвячена історії монастиря; у 1890 р. - довідник монастирів Російської імперії В. Звєрінського (1835-1893), та ін. ${ }^{7}$ Інколи вони ще 3'являлися в періодиці різних років, змальовуючи місцевий колорит, як, наприклад, 1943 року в газеті «Нова Україна», що друкувалася в Полтаві в період окупації. Чи не найбільш красномовно легенду про Мотронинський монастир описав відомий військовий діяч Юрій Горліс-Горський (1898-1946) у своїх спогадах у 1936 році ${ }^{9}$. Сучасний же черкаський краєзнавець Юрій Мариновський (1952-2020) відзначав, що легенда про княгиню Мотрону має кілька варіантів ${ }^{10}$. Нині вона популярна у краєзнавчій та церковній літературі ${ }^{11}$.

Виникає питання, хто ж був творцем міфу про княгиню Мотрону і заснування нею Мотронинського монастиря? Відповідь напрошується тільки одна - чернецтво цієї ж

${ }^{1}$ Круг Ф. О мнимо Матренинской монете // Вестник Европы. 1819. Часть 103. №3. С. 195-196.

ЦДІАУК. Ф. 180. Оп. 1. Спр. 19. Арк. 5.

3 Wroth W. Catalogue of the imperial Bizantine Coins in the British Museum. Vol. 1. London, 1908. P. 54; David R. Sear. Bizantine coins and their values. London, 1974. P. 19

${ }^{4}$ Whitting P.D. Bizantine Coins. New York, 1973. P. 100.

5 Шостопал А. Скарби Черкащини. С. 47.

${ }^{6}$ Кулиш П. Записки о Южной Руси. К., 1994. С. 142.

Матронинский Св. Троицкий монастырь // Киевские епархиальные ведомости. 1864. №20. С. 621-629; Зверинский В. Материал для историкотопографического исследования о православных монастырях. Т. ІІ. СПб., 1892. С. 209.

${ }^{8}$ Мельник О. Сміла // Нова Україна. 29 серпня 1943 р. Число 128 (442). С. 6.

9 Горліс-Горський Ю. Холодний Яр. Львів, 1992. С. 32-33.

${ }_{10}$ Мариновський Ю. Мотронинський монастир. Черкаси, 1990. С. 2.

${ }^{11}$ Нескорений велет. Сторінки з історії Свято-Троїцького Мотронинського монастиря / Упор.: прот. Петро Дмитрук та ін. Черкаси, 2004. 223 с.; Свято-Троицкий Мотренинский монастырь. Б.м., б.г. 12 с. 
обителі. Кому саме і коли саме прийшла така думка в голову, зараз уже важко сказати. Проте, очевидно, що це сталося на початку XIX ст., а безпосередньо причетним до цього слід вважати одного із тодішніх ігуменів.

Як видно із опублікованого у 1819 р. матеріалу, Ф. Круг отримав монету від канцлера Миколи Рум'янцева 30 грудня 1818 р. і в той же день надіслав йому відповідь у вигляді листа. Того дня вчений перебував у Санкт-Петербурзі. Можливо, що і сам канцлер перебував у цей час саме там. В усякому разі, саме від нього монета надійшла на експертизу до Ф. Круга. Зацікавленість же канцлера цією історією із монетою цілком зрозуміла. На той час він був відомим меценатом, колекціонером і покровителем науки. Саме М. Рум'янцев ще у 1811 р. виступив організатором створення Комісії з друкування державних грамот і договорів («Комиссия печатания государственных грамот и договоров»), намагався об’єднати істориків для їх співпраці у сфері історичних досліджень, спонсорував видання їх праць, стимулював до пошуку і виявлення історичних документів та пам'яток. Неодноразово канцлер бував і у Києві, де, до речі, на території Києво-Печерської лаври похований його батько - генерал-фельдмаршал Петро Рум’янцев-Задунайський (1725-1796). Зокрема, перебування у Києві у вересні 1814 р. М. Рум'янцева відмічає у своїх щоденниках київський митрополит Серапіон (Александровський) (1747-1824) ${ }^{1}$. Окрім того, канцлер був знайомий та підтримував постійні контакти не лише з багатьма імперськими та зарубіжними істориками того часу, а й з уже згадуваними Амвросієм (Орнатським) та Свгенієм (Болховітіновим) $)^{2}$, від яких вперше було отримано інформацію про монети з Мотронинського городища. Тому не дивно, що канцлера зацікавила легендарна історія з княгинею Мотроною, заснуванням нею монастиря та ще й знахідкою монет, які начебто їй належали.

Сам монастир у той час активно розвивався. Після приєднання земель Правобережної України до складу Російської імперії внаслідок поділу Речі Посполитої новою владою звертається особлива увага на розбудову церковних структур на цих територіях. Економічно монастирі стають поступово більш міцними, що дозволяє їм займатися облаштуванням власної території та будівництвом нових храмів i господарських споруд.

Від початку XIX століття якраз і спостерігаємо таке будівельне піднесення у Мотронинському монастирі: 1802-1804 pp. - споруджується центральний Троїцький храм, 1812 р. - нова дерев'яна дзвіниця, 1820 р. - трапезна дерев'яна церква в ім'я Іоанна Златоуста. Вочевидь, що саме під час цієї будівельної активності, що охоплювала всю територію монастиря, і були знайдені відповідні монети. Далі ж відбувається банальна річ: оскільки на одній із монет було виявлено літеру «М», відповідно, її було прив’язано до назви лісу і самого монастиря. За аналогією із російськими монетами, де завжди значилися перші літери імен російських імператорів, починаючи від Петра I («П», «Е», «А»), було зроблено висновок про їхню належність княгині Мотроні («М»- Мотрона). Так, власне, і з'явилася легенда про заснування монастиря. Можливо, до творення легенди про заснування обителі був причетний їі ігумен Антоній (помер у 1807 р.) або ж уже його наступник, ігумен Досифей.

Оскільки ігумени всіх монастирів щорічно звітували перед вищими церковними органами (у 1789-1832 рр. у рамках Київської митрополії роль канцелярії виконувала Київська духовна дикастерія), вони обов'язково повинні були надавати повну інформацію про дійсний стан обителі та історичні відомості. Завдяки збору такої інформації і вдалося Амвросію (Орнатському) та Свгенію (Болховітінову) укласти і видати у 1807-1815 роках свою «Историю российской иерархии», де й було вперше опубліковано згадану легенду.

Терновский Ф. Хроника киевской общественной жизни по дневнику митрополита Серапиона (1804-1821) // Киевская старина. 1884 . №7. С. 457. 2 Козлов В. Колумбы российских древностей. М., 1981. 168 с. 
Для 3'ясування ситуації із назвами «Мотрин/Мотронинський ліс» чи «Мотрин/Мотронинський монастир» та їх зв'язку із легендою про «княгиню Мотрону» можна виходити 3 такого:

1) до середини XVII ст. ці назви не були відомі, вони ніде не фіксуються. Сама назва «Мотронинський» стосовно монастиря вперше з'являється у джерелах тільки 1671 року в універсалі Петра Дорошенка, що адресувався цьому ж монастирю. Всі посилання на більш ранні часи мають більш пізній характер (починаючи з XVIII ст.), тобто автоматично здійснюється ототожнення вже існуючої назви з більш раннім можливим об'єктом (хоча, насправді, не доведено і його існування);

2) легенда про княгиню Мотрону невідома до початку XIX ст. в жодних записах. Монастирські документи також про неї мовчать до цього часу. І достатньо красномовний у цьому контексті переказ про заснування монастиря, зафіксований у 1746 р., за яким його фундатором називається переяславський єпископ Павло, діяльність котрого відноситься ще до часів Русі ${ }^{1}$. Тобто, у XVIII ст. у Мотронинському монастирі його заснування ніяким чином не пов'язували з якоюсь міфічною Мотроною;

3) легенди про Мотрону (в усіх варіантах, які дійшли до сьогодні) мають достатньо складну структуру, в якій цілком очевидно присутні і місцевий характер, i складні соціальні відносини. На жаль, детального аналізу цих легенд здійснено не було, тому важко говорити про те, в який історичний період ці легенди формувалася і коли доповнювалися побутовими деталями. Однак очевидно, що в них на перше місце виходить не релігійність, а звичайне життя з його переживаннями і почуттями. Можна вважати, що більш давній переказ дійсно був пов’язаний з іменем якоїсь реальної історичної особи, від імені якої і отримав назву місцевий лісовий масив (можливо, це пов'язано із питанням володіння, трагічної події тощо). Водночас слід звернути увагу й на те, що Кіндрат Тарануха зі Сміли назвав Мотрону не княгинею, а дочкою пана, що, скоріш за все, є відголоском саме тієї давньої легенди, а ототожнення саме з княгинею виникло вже на початку XIX ст.

Висновки дослідження й перспективи подальших досліджень. Таким чином, ми можемо простежити, як знахідка двох візантійських монет на території Мотронинського городища вплинула на формування історичної легенди. Результатом цього стало те, що нумізматичний матеріал виступив не лише джерелом історичної інформації, а й джерелом легенди.

\section{REFERENCES}

Antonovich V. (1895). Arheologicheskaya karta Kievskoy gubernii [Archaeological map of the Kiev province]. Kiev. 139, 20 s. [in Russian].

Belyashevskiy N. (1889). Monetnyie kladyi Kievskoy gubernii [Coin treasures of the Kiev province]. Kiev. 149 s. [in Russian].

Bobrinskiy A. (1894). Kurganyi i sluchaynyie arheologicheskie nahodki bliz mestechka Smelyi [Mounds and random archaeological finds near the town of Smela]. T. II. SPb., 1894. 232 s. [in Russian].

David R. Sear. (1974). Bizantine coins and their values. London. 412 p. [in English]

Horlis-Horskyi Yu. (1992). Kholodnyi Yar [Cold Yar]. Lviv. 342 s. [in Ukrainian]

Istoriya rossiyskoy ierarhii (1813) [History of the Russian hierarchy]. Chast V. Moskva. 737 s. [in Russian]. 
Kotsur V. (2017) Istoriohrafiia ukrainskoho skarboznavstva [Historiography of the ukrainian treasurology] Ukrainskyi numizmatychnyi shchorichnyk. Vyp. 1. 2017. S. 15-32. [in Ukrainian].

Kostomarov N. (1989). Istoricheskie proizvedeniya. Avtobiografiya [Historical works. Autobiograph]. Kiev. 736 s. [in Russian].

Kozlov V. (1981). Kolumbyi rossiyskih drevnostey [Columbus of Russian antiquities]. Moskva. 1981. 168 s. [in Russian].

Kropotkin V. (1962). Kladyi vizantiyskih monet na territorii SSSR [Treasures of Byzantine coins on the territory of the USSR.]. Moskva. 64 s. [in Russian].

Kropotkin V. (1954). Topografiya rimskih i rannevizantiyskih monet na territorii SSSR [Topography of Roman and Early Byzantine coins on the territory of the USSR]. Vestnik drevney istorii. №3. S. 152-180. [in Russian].

Krug F. (1819). O mnimo Matreninskoy monete [About the imaginary Matreninsky coin]. Vestnik Evropyi. Chast 103. №3. S. 195-198. [in Russian]. Russian].

Kulish P. (1994). Zapiski o Yuzhnoy Rusi [Notes on Southern Russia]. Kiev. 719 s. [in

Lastovskyi V. (2008). Mizh suspilstvom i derzhavoiu. Pravoslavna tserkva v Ukraini naprykintsi XVII - $u$ XVIII st. $v$ istorii ta istoriohrafii. [Between society and the state. The Orthodox Church in Ukraine in the late XVII - XVIII centuries in history and historiography]. Kyiv. 496 p. [in Ukrainian].

Marynovskyi Yu. (1990). Motronynskyi monastyr [Motroninsky Monastery]. Cherkasy. 60 s. [in Ukrainian].

Matroninskiy Sv. Troitskiy monastyir (1864) [Matroninsky Holy Trinity Monastery]. Kievskie eparhalnyie vedomosti. №20. S. 621-629. [in Russian].

Melnyk O. (1943). Smila [Smila]. Nova Ukraina. 29 serpnia 1943 r. Chyslo 128 (442). [in Ukrainian].

Neskorenyi velet. Storinky z istorii Sviato-Troitskoho Motronynskoho monastyria (2004) [Unconquered giant. Pages from the history of the Holy Trinity Motroninsky Monastery]. Upor.: prot. Petro Dmytruk ta in. Cherkasy. 223 s. [in Ukrainian].

Pohilevich L. (1864). Skazaniya o naselennyih mestnostyah Kievskoy gubernii [Tales of the populated areas of the Kiev province]. Kiev. 763 s. [in Russian].

Shostopal A. (2007). Skarby Cherkashchyny [Treasures of Cherkasy region]. Cherkasy. 120 s. [in Ukrainian].

Svyato-Troitskiy Motreninskiy monastyir [Holy Trinity Motreninsky Monastery]. B.m., b.g. 12 s. [in Russian].

Ternovskiy F. (1884). Hronika kievskoy obschestvennoy zhizni po dnevniku mitropolita Serapiona (1804-1821) [Chronicle of Kiev public life according to the diary of Metropolitan Serapion (1804-1821)]. Kievskaya starina. 1884. №7. S. 423-466. [in Russian].

Tsentralnyi derzhavnyi istorychnyi arkhiv Ukrainy $v$ m. Kyiv (TsDIAUK) [Central State Historical Archive of Ukraine in Kyiv]. F. 180. Op. 1. Spr. 19.

Zverinskiy V. (1892). Material dlya istoriko-topograficheskogo issledovaniya o pravoslavnyih monastyiryah [Material for historical and topographical research on Orthodox monasteries]. T. II. SPb. 462 s. [in Russian].

Wroth W. (1908). Catalogue of the imperial Bizantine Coins in the British Museum. Vol. 1. London. 312 p. [in English].

Whitting P.D. (1973). Bizantine Coins. New York. 311 p. [in English]. 